\title{
Solid state bioprocessing for scale up of Aspergillus tamarii MTCC5152 lipase and its degreasing effect on cow hide
}

\author{
A. Dayanandan*, S. Hilda Vimala Rani, M. Shanmugavel, A.Gnanamani, and G. Suseela Rajakumar \\ Department of Microbiology, Central Leather Research Institute (CSIR-New Delhi) Adyar, Chennai-600020, India \\ asdaya17@gmail.com
}

\begin{abstract}
To scale up lipase production process, the effects of different oil cakes and oils as substrates in solid state fermentation (SSF) were investigated. Combination of wheat bran (WB) with gingelly oil cake (GOC) and gingelly oil was observed to be suitable medium for the scale up of lipase. Wheat bran and gingelly oil cake in the ratio of 8:2 along with $0.5 \%$ gingelly oil showed $998 \mathrm{u} / \mathrm{g}$ of lipase activity in perforated steel trays in koji room cultivation. When compared to flask both enamel tray and perforated steel trays in koji room level scale up studies showed an enhanced production by $12.1 \%$ and $26.1 \%$, respectively. A combination of gingelly oil cake and wheat bran exhibited bulk production of lipase in the koji room with shorter period of incubation. Application of 3\% of Aspergillus tamari lipases offered maximum degreasing in the hide and the results are comparable to the commercial enzymatic process.
\end{abstract}

Keywords: Wheat bran, oil cakes, lipase, scale up production, Aspergillus tamarii MTCC5152.

Introduction

Among the allknown microbial enzymes, lipase constitutes the versatile biotechnological tool and most important group of biocatalysts for biotechnological applications (Reetz 2002; Kishore et al., 2011; Sangeetha et al., 2011). Lipases are versatile catalyst and have drawn the attention of much research for the production of biodiesel (Zhang et al., 2011; Lee et al., 2011). Blends of lipase with other enzymes are used in detergent industries and as dietary supplement (Harwood 1989). Fungal lipases are one of the commercially important industrial enzyme and has many applications viz food, detergent and leather industries and are an important tool in studying the structure of protein and peptides (Jaeger \& Reetz 1998; Dierick\& Decuupere, 2002).

Well known microbial lipases are derived from a wide variety of yeasts, molds and bacteria (Balaji \& Ebenezer, 2008; Jayaprakash \& Ebenezer, 2010). Fungal lipases offer a distinct advantage over bacterial enzymes in terms of ease of downstream processing. A large proportion of commercially available lipases are currently derived from Aspergillus strains, although potential use of fungal lipases is being increasingly realized (Contesini, 2010). In recent years, solid state cultures gained much consideration in production of microbial lipases through solid state fermentation (SSF) by filamentous fungi which utilizes low-cost agricultural residues as substrates, economic space, and gives high yield (Gombert et al., 1999; Pandey et al., 2000; Gutarra et al., 2005). Agro based substrate not only supports and stimulates the secondary metabolite production under optimized conditions but also gives nutrients and anchorage to the cells (Emtiazi et al., 2003; Wang et al., 2008).

About $40-45 \%$ of the production cost of industrial enzymes is estimated to be the cost of the growth medium. Therefore, there is a strong need to optimize the conditions for cost-effective scale up production of lipase. Environmental pollution caused by chemical-based industries necessitates the development of

Research article "Lipase"

CIndian Society for Education and Environment (iSee)

http://www.indjst.org environmentally friendly processes as an alternative to currently employed chemical method. In this regard, lipase based enzyme technology has potential to replace the conventional method (Dayanandan et al., 2003). The present study was investigated to optimize various process parameters using low cost oil rich solid substrate for the production of lipase and its application potential for degreasing operation in leather processing. The aim of the present work is to analyze the efficiency of microbial source and efficacy of mixed oil rich substrates containing various oil cakes for scale up production of lipase by A.tamariMTCC5152 and evaluate the degreasing potential of lipase in ecofriendly leather processing.

Materials and methods

Analytical grade chemicals purchased from $\mathrm{Hi}$-media were used in this study. Wheat bran, different oil cakes (gingelly, groundnut, cotton seed and coconut) and oils (olive, gingelly, coconut and groundnut) have been purchased from local supplier. Aspergillus tamarii MTCC 5152 used in the present work was isolated from tannery effluent soil and maintained on CzapekDox's agar slants. Spore suspension from 7 day old slant culture raised on Czapek Dox's agar incubated at $28 \pm 2^{\circ} \mathrm{C}$ containing $0.1 \%$ Tween-80 was used as an inoculum after adjusting the desired spore count using a haemocytometer. Spore suspension was filtered aseptically and appropriate volume was used.

\section{SSF and fermentation conditions}

Erlenmeyer flasks $(250 \mathrm{ml})$ containing $8 \mathrm{~g}$ of wheat bran and $2 \mathrm{~g}$ of powdered oil cakes (gingelly, ground nut, cotton seed and coconut oil cakes) were moistened with $7.0 \mathrm{ml}$ water $(70 \% \mathrm{v} / \mathrm{w})$ and sterilized at $121{ }^{\circ} \mathrm{C}$ for 15 $\mathrm{min}$. After cooling, the flasks were inoculated with spore suspension $(1.0 \mathrm{ml})$ containing $10^{6}$ spores $/ \mathrm{ml}$. The contents of each flask were mixed thoroughly with a sterile glass rod for uniform distribution of fungal spores in the medium and incubated at $28{ }^{\circ} \mathrm{C}$ in temperature controlled incubator at static condition for the fungal growth. After the incubation period, the ferment from each 
flask were extracted with phosphate buffer and the enzyme activities were estimated every $24 \mathrm{~h}$ intervals for a period of 6 days. In addition the effect of various oils on enzyme production was studied by adding $0.5 \% \mathrm{w} / \mathrm{w}$ of olive, gingelly, coconut and groundnut oil to the best substrate selected in this study. The flasks were then inoculated, incubated, extracted and enzyme activities were assayed as described above.

\section{Extraction and enzyme assay method}

The mouldy agricultural residue was thoroughly mixed with $1: 10$ ratio of $0.1 \mathrm{M}$ phosphate buffer, $\mathrm{pH} 7.0$ containing $0.1 \%$ Tween- 80 , in an orbital shaker filtered and centrifuged at $10,000 \mathrm{rpm}$ for $15 \mathrm{~min}$ in a refrigerated centrifuge and used as a crude enzyme extract. Two methods were adopted to assay the lipase activity. Enzyme activity was assayed through alkali titration with olive oil emulsion as the substrate, using a modified version of the procedure described by Saxena et al. (2003). In brief, the assay mixture consisting $5 \mathrm{ml}$ of olive oil emulsion, $4 \mathrm{ml} 0.1 \mathrm{M}$ phosphate buffer $(\mathrm{pH} 7.0)$ and 1 $\mathrm{ml}$ crude enzyme extract was mixed well and incubated for $20 \mathrm{~min}$ at $37^{\circ} \mathrm{C}$. The reaction was stopped by the addition $20 \mathrm{ml}$ acetone. The mixture was then titrated with $0.05 \mathrm{M} \mathrm{NaOH}$ in the presence of phenolphthalein $(0.1 \mathrm{ml})$ as indicator. The titre values were used to calculate for lipase activity. One unit of lipase activity is defined as the amount of enzyme required to release $1 \mu \mathrm{mol}$ of fatty acid per minute under the standard assay conditions. To confirm the lipase activity spectrophotometric method was also performed (Kwon and Rhee, 1986) and a good agreement has been noted between the results obtained using the two methods. Protein content of the crude enzyme extract was analyzed by the method of Lowry et al. (1951) and total free fatty acid content released was estimated according to the method of Saxena et al. (2003).

Process optimization studies for lipase production

Solid state cultivation in flasks: For the flask production wheat bran $8 \mathrm{~g}$ and oil cakes $2 \mathrm{~g}$ were used for the growth conditions were described in section 2.2. The parameters studied were effect of various oil cakes, addition of different oil sources, initial moisture content, and inoculum size and incubation period. The parameters optimized each time were incorporated in subsequent experiments conducted during the present study. Lipase activities were expressed in units per gram of dry weight of the fermented substrate $(\mathrm{u} / \mathrm{g})$.

Scale up process: The fungal strain was cultivated in enamel trays $\left(20 \times 8 \times 5 \mathrm{~cm}^{3}\right)$ containing $300 \mathrm{~g}$ substrates (240 g of of wheat bran and $60 \mathrm{~g}$ of gingelly oil cake) moistened to $70 \% \mathrm{v} / \mathrm{w}$ with distilled water. All other conditions were maintained as optimized for $250 \mathrm{ml}$ Erlenmeyer flasks as mentioned earlier. The trays were covered with perforated aluminium foil and sterilized at $121^{\circ} \mathrm{C}$ for $20 \mathrm{~min}$, cooled, and then inoculated with $5 \%$ of 7 day old inoculum. The trays were incubated in a temperature controlled incubator at $27^{\circ} \mathrm{C}$, at $90-95 \%$ relative humidity for $144 \mathrm{~h}$. Samples were withdrawn at desired intervals, and lipase was assayed as described in section 2.3. Scales up studies were done in a koji room with $3 \mathrm{~kg}$ of substrate in each perforated steel trays $(3 \mathrm{ft}$ by $1 \mathrm{ft}$ by 2 inch). The substrate chosen for flask level studies were used in scale up studies also. The substrates were inoculated with $5 \%$ of 7 day old inoculum and incubated for $144 \mathrm{~h}$. All the parameters and other conditions studied were as optimized in $250 \mathrm{ml}$ Erlenmeyer flasks as mentioned earlier. The koji room temperature was maintained at $27^{\circ} \mathrm{C}$ and the humidity was kept at 90 to $95 \%$. The scale up studies conducted in Koji room was effect of moisture content, inoculum size and incubation period. Samples were withdrawn at desired intervals, and lipase activity was assayed.

Degreasing of cow hide using lipase: Hides were processed as per the standard procedure (Puvanakrishnan \& Dhar, 1998). The dehaired hide up to $15 \times 20 \mathrm{~cm}$ were subjected to degreasing using $A$. tamarii MTCC5152 lipase and commercial enzymatic degreasing agent and the samples were kept under shaking in a drum for 4 hours. The liquor was collected and estimated for the amount of free fatty acid liberated from the hide according to Saxena et al. (2003). All

Fig. 1. Effect of oil cakes at flask level (10g) lipase production

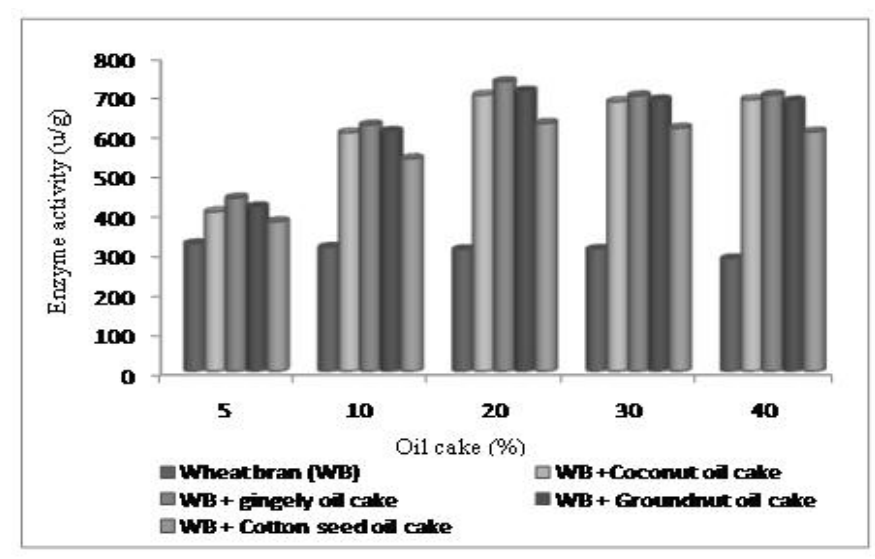

Fig. 2. Effect of oil cakes at enamel tray level (300 g) lipase production

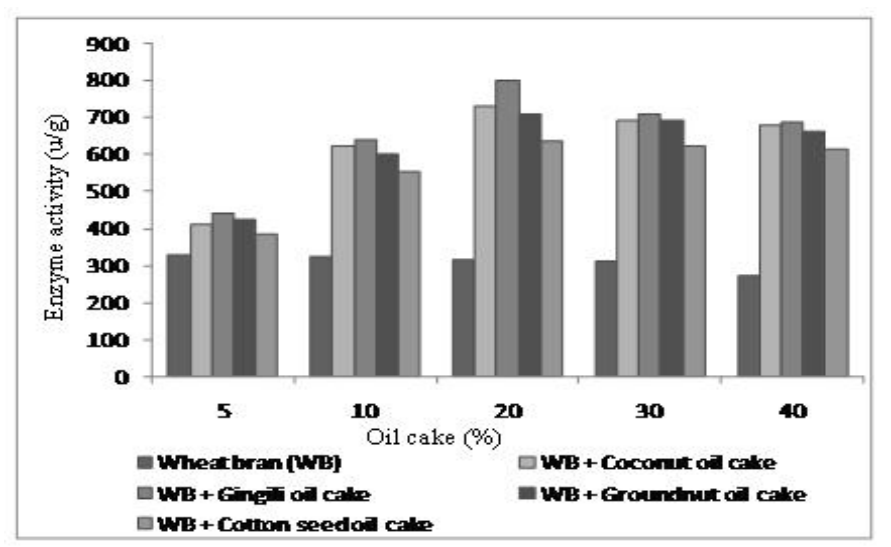

Research article

(C)Indian Society for Education and Environment (iSee)
"Lipase"

http://www.indjst.org
Dayanandan et al. Indian J.Sci.Technol. 
experiments were done in triplicate and the values presented are the means of three independent determinations.

\section{Results}

Effect of combination of wheat bran with various oil cakes on enzyme production

Ideal agro-based oil cakes for lipase production in a solid-state fermentation process based on cost and availability of such substrates were identified and screened. The results of the present study (Fig. $1 \& 2$ ) indicate that lipase production pattern varied with the type of agro-oil cakes. Maximum enzyme activity was obtained when combination of wheat bran $(80 \%)$ and gingelly oil cake $(20 \%)$ was used, compared to the other substrate combination.

Table 1. Effect of addition of oils on lipase production in flasks

\begin{tabular}{|l|l|l|}
\hline \multirow{2}{*}{ Substrate } & $96 \mathrm{~h}$ & $120 \mathrm{~h}$ \\
\cline { 2 - 3 } & \multicolumn{2}{|c|}{ (Lipase u/g) } \\
\hline WB & 552 & 574 \\
\hline WB +GOC & 611 & 735 \\
\hline WB + GOC + Gingellyoil & 753 & 792 \\
\hline WB + GOC + Coconut oil & 652 & 757 \\
\hline WB + GOC + Groudnut oil & 665 & 761 \\
\hline WB + GOC + Olive oil & 748 & 782 \\
\hline
\end{tabular}

Fig. 3. Effect of concentration of gingili oil on lipase production

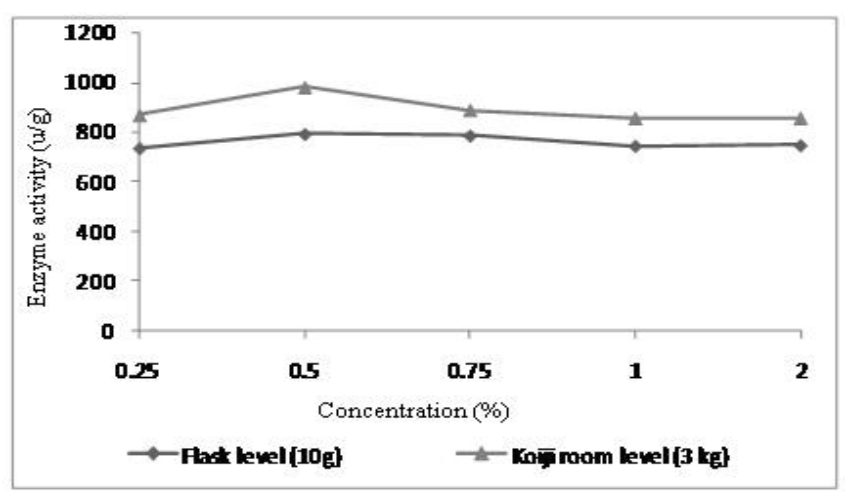

Fig. 4. Effect of initial moisture content on lipase production

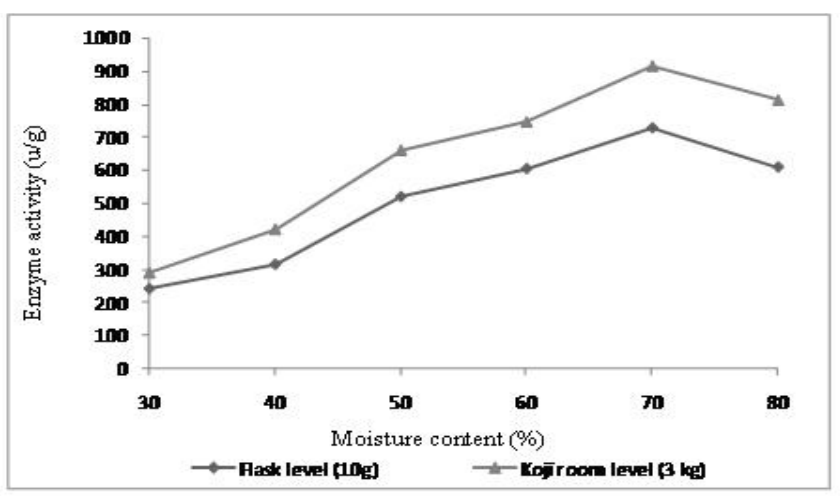

Effect on addition of various oils on the production of lipase

Addition of various oils in different combination with wheat bran and gingelly oil cake on enzyme production was studied. It is revealed that the maximum lipase activity (Table. 1 ) was obtained when $0.5 \%$ gingelly oil was added to wheat bran containing gingelly oil cake $(977 \mathrm{u} / \mathrm{g})$.

Effect of various concentration of gingelly oil on lipase production

Fig. 3 shows the results on the effect of addition of different concentration of gingelly oil on lipase production. Maximum lipase activity was found when $0.5 \%$ gingelly oil was added to wheat bran containing gingelly oil cake (989 u/g).

\section{Effect of initial moisture content}

The initial moisture content is a crucial factor that affects the product formation through solid state fermentation. To check the influence of moisture on lipase activity during SSF, the flask $(10 \mathrm{~g})$ and Koji room level $(3 \mathrm{Kg})$ fermentation substrates were moistened with different percentage (30-80\%) of moisture and the results are shown in Fig. 4. Wheat bran and gingelly oil cake at $70 \%$ moisture content produced maximum lipase activity $(914 \mathrm{u} / \mathrm{g})$. In flask level experiment the enzyme

Fig. 5. Effect of inoculum size on lipase production

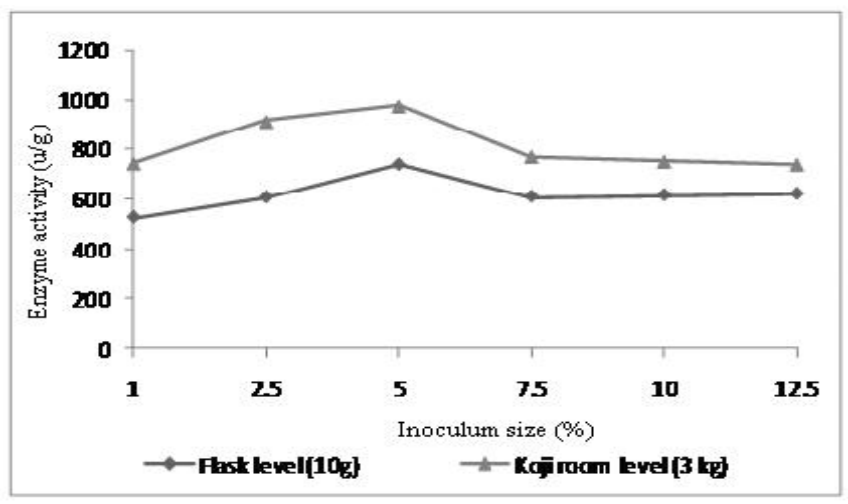

Fig. 6. Effect of incubation time on lipase production

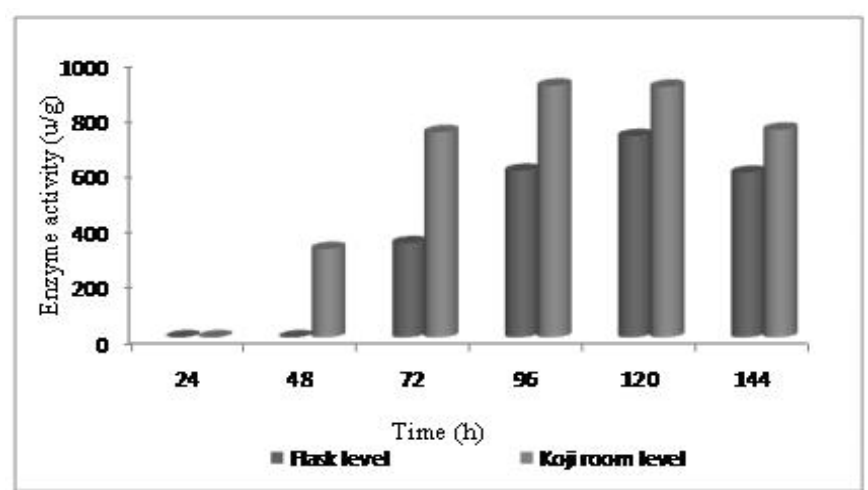

Dayanandan et al. Indian J.Sci.Technol. 
production was found to be declined when the moisture content was above or below $70 \%$.

Effect of inoculum size

Fig. 5 shows the results on the effect of different inoculum level (1-12.5\%) for the maximum production of lipase in flask $(10 \mathrm{~g})$ perforated steel trays in Koji room level $(3 \mathrm{~kg})$ studies. $5 \%$ inoculum shows the maximum lipase activity in both types of cultivations. Lower or higher inoculum size did not support the increase in production.

\section{Effect of incubation period}

During the course of study, enzyme activity was detected in the culture extracts of all the experimental samples with a different level of production. Maximum activity was found after $120 \mathrm{~h}$ in flask studies with an activity of $731 \mathrm{u} / \mathrm{g}$. In Koji room cultivation, maximum activity $(914 \mathrm{u} / \mathrm{g})$ was obtained after $96 \mathrm{~h}$ of incubation (Fig. 6). A steady decline in enzyme yield was observed after $120 \mathrm{~h}$ of incubation.

Table 2. Comparison of lipase production by A.tamarii in various levels of SSF

\begin{tabular}{|c|c|c|c|c|c|}
\hline Substrate & Flask & $\begin{array}{c}\text { Enamel } \\
\text { tray }\end{array}$ & $\begin{array}{c}\text { Koji } \\
\text { room }\end{array}$ & $\begin{array}{c}\text { Comparison between } \\
\text { flask and tray culture }\end{array}$ & $\begin{array}{c}\text { Comparison } \\
\text { between flask } \\
\text { and Koji room } \\
\text { culture }\end{array}$ \\
\cline { 2 - 6 } & \multicolumn{3}{|c|}{ (Lipase u/g) } & \multicolumn{2}{|c|}{ (\% increase) } \\
\hline $\begin{array}{c}\text { WB + } \\
\text { GOC }\end{array}$ & 736 & 801 & 908 & 8.8 & 23.3 \\
\hline $\begin{array}{c}\text { WB+OC+ } \\
\text { Gingelly oil }\end{array}$ & 791 & 887 & 998 & 12.1 & 26.1 \\
\hline
\end{tabular}

Comparative study on lipase yield in flask, enamel trays and Koji room production

Several researches have claimed that the SSF in tray culture gives greater enzyme yield than flask (SolisPereira et al., 1993; Pandey et al.,1999) and the data shown in Table. 2 shows a comparative evaluation on the lipase yield by $A$. tamarii MTCC5152 in flasks, enamel tray and perforated steel trays in Koji room level production. When compared to other two levels, perforated steel trays in Koji room levels culture accomplished $23.3 \%$ increase in enzyme yield using gingelly oil cake. It is further enhanced to $26.1 \%$ of enzyme production by the addition of gingelly oil.

Degreasing studies using A. tamarii MTCC5152 lipase

Table. 3 shows that the application of $4 \%$ of $A$. tamari MTCC 5152 lipase shows maximum degreasing effect. The results were comparable with control samples processed using commercial degreasing agents.

\section{Discussion}

Maximum production of lipase was obtained with

Table 3. Degreasing effect of commercial enzymatic agents and A.tamarii lipase in of hide

\begin{tabular}{|l|l|}
\hline Hide treated with Lipase & Free acid released (\%) \\
\hline $\begin{array}{l}\text { Control [Commercial enzymatic } \\
\text { degreasing agent (4\%)] }\end{array}$ & 100 \\
\hline A.tamarii lipase 2 \% & 50 \\
\hline A.tamarii lipase 3 \% & 69 \\
\hline A.tamarii lipase 4 \% & 92 \\
\hline A.tamarii lipase 5\% & 90 \\
\hline
\end{tabular}

Research article

(C)Indian Society for Education and Environment (iSee) combination of wheat bran and gingelly oil cake as a fermentation media. It could be attributed to the solid material's dual role: supply of nutrients for microbial growth and anchorage for the growing mycelia. SSF by Aspergillus species using certain oil cakes were showed to induce lipase production (Kamini et al., 1998; Iluyemi et al., 2006). In this investigation gingellyoil cake was used for further studies. Supplementation of oil source showed a mild improvement in the production. Addition of olive oil induce the lipase production of Staphylococcus sp. Lp12 (Pogaku et al. 2010) and A. niger (Colin et al., 2010). Immanuel et al. 2008 observed that lipases are inducible enzymes and can be induced in appreciable amount with gingelly oil by Serratia rubidaea. The lipase activity was improved by the addition of castor oil in $A$. niger grown in solid-state fermentation (Dutra et al., 2008).

From the growth parameters, it is evident and also established, that lower moisture levels leads to particle agglomeration, limitation in gas transfer, and competition from microbes. Szendefy et al. (2006) reported that the highest yield of xylanase by $A$. oryzae was attained at $80 \%$ initial moisture content on eucalyptus and bagasse pulp as substrate. $5 \%$ inoculum is sufficient for optimal level of mycelium production and enzyme as well. Toshiko et al. (1989) reported that $5 \%$ of inoculum gave maximum production of lipase by Rhizopus oligosporous. Increase in mycelial mass at higher inoculum level, reduces the production of enzyme due to exhaustion of nutrients in the fermentation medium. Maximal lipase production by Streptomyces sp. was reported after $120 \mathrm{~h}$ of incubation (De Azeredo et al., 2004). Penicillium sp. in SSF showed maximum activities after $72 \mathrm{~h}$ (Yang et al., 2000; Agarwal et al., 2003). The decline in lipase production after the optimum period in both the experimental set up (flask, koji room) could be due to depletion of nutrients available to the fungus cells. During the microbial cultivation, the depletion of nutrients decreases the production of enzymes (Chu et al., 1992; Gupta et al., 2002).

It is significant to note that in Koji room, lesser period of incubation was sufficient to achieve optimum enzyme production. This might be due to conducivegrowth condition and anchorage to the mycelia as well as availability of nutrients in the SSF medium. There was an increased production of lipase in koji room compare to flasks and enamel tray, may be due to proper aeration followed by better biomass, and heat transfer from the fermentation media. Scale up studies of xylanase shows an increment in production (Archana \& Sathyanarayan, 1997). It has been reported that combination of gingelly oil cake and wheat bran and rawa induces better lipase production (Edwinoliver et al., 2010). Based on scale up studies results from koji room investigation, pilot scale production $(25 \mathrm{~kg}$ ) of lipase by $A$. tamarii MTCC5152 was 
conducted. It may be possible to achieve higher level of lipase production with increase in quantities of the potential solid substrate wheat bran and gingelly oil cake using $A$. tamarii MTCC5152 in the koji room. Application of $A$. tamarii lipase on hide shows a best degreasing effect. Afsar and Cetinkaya (2008) reported that an application of lipase to goat skin shows the best degreasing effect and a combination of alkaline lipase and alkaline protease gave a better degreasing.

\section{Acknowledgements}

One of the authors (A. Dayanandan) is thankful to the Council of Scientific and Industrial Research (CSIR), New Delhi for the award of Senior Research Associateship.

\section{References}

1. Afsar A and Cetinkaya F (2008) Studies on the degreasing of skin by using enzyme in liming process. Ind.J. Technol. 15, 507-510.

2. Agarwal $D, P a t i d a r P$, Banerjee $T$ and Shridhar $P$ (2005) Production of alkaline protease by Penicillium sp. under SSF conditions and its application to soy protein hydrolysis. Process Biochem. 40, 1131-1136.

3. Archana A and Satyanarayana T (1997) Xylanase production by thermophilic Bacillus licheniformis A99 in solid-state fermentation. Enzyme Microbiol. Technol. 21, 12-17.

4. Balaji V and Ebenezer P (2008) Optimization of extracellular lipase production in Colletotrichum gloeosporioides by solid state fermentation. Indian $\mathrm{J}$. Sci. Technol. 1 (7), 1-8.

5. Chu IM, LeeC and Li TS (1992) Production and degradation of alkaline protease in batch cultures of Bacillus subtilis ATCC 14416. Enzyme Microbiol. Technol. 14, 755-761.

6. Colin VL, Baigori MD and Pera LM (2010) Effect of environmental conditions on extracellular lipases production and fungal morphology from Aspergillus niger MYA 135. J Basic Microbiol. 50, 52-58.

7. Contesini FJ, Lopes DB, Macedo GA, Nascimento MG and Carvalho PO (2010) Aspergillus sp. lipase: Potential biocatalyst for industrial use. J. Mol.Catal. Enzyme. B67, 163-171.

8. Dayanandan A, Kanagaraj J, Lesley S, Govindaraju R and Suseela Rajkumar G (2003) Application of an alkaline protease in leather processing: an ecofriendly approach. J. Clean Prod.11, 533-536.

9. De Azeredo LAI, Freire DMG, Soares RMA, Leite SGF and Coelho RRR (2004) Production and partial characterization of thermophilic proteases from Streptomyces $s p$. isolated from Brazilian cerrado soil. Enzyme Microbiol. Technol. 34, 354-358.

10.Dierick N and Decuypere J (2002) Endogenous lipolysis in feedstuffs and compound feeds for pigs: effects storage time and conditions and lipase and/or emulsifier addition. Anim. Feed Sci. Technol.102, 5370.
11.Dutra JC, Terzi SC, Bevilaqua JV, Damaso MC, Couri S, Langone MA and Senna LF (2008) Lipase production in solid-state fermentation monitoring biomass growth of Aspergillus niger using digital image processing. Appl.Biochem.Biotechnol.147, 6375.

12. Edwinoliver NG, Thirunavukarasu K, Naidu RB, Gowthaman MK, Nakajima Kambe T and Kamini NR (2010) Scale up of a novel tri-substrate fermentation for enhanced production of Aspergillus niger lipase for tallow hydrolysis. Bioresour. Technol.101, 6791-6796.

13.Emtiazi G, Habibi MH and Taheri AR (2003) Production of thermostable extracellular lipase by Pseudomonas grown on cotton cake and cod removal of sunflower oil waste. Fresenius Environ. Bul.12, 704708.

14.Gombert AK, Pinto AL, Castilho LR and Freire DMG (1999) Lipase production by Penicillium restrictum in solid-state fermentation using babassu oil cake as substrate. Process Biochem. 35, 85-90.

15.Gupta R, Beg QK, Khan S and Chauhan B (2002) An overview on fermentation, downstream processing and properties of microbial proteases. Appl.Microbiol.Biotechnol. 60, 381-395.

16. Gutarra MLE, Cavalcanti EDC, Castilho LR, Freire DMG and Sant'Anna Jr GL (2005) Lipase production by solid-state fermentation: cultivation conditions and operation of tray and packed-bed bioreactors. Appl.Biochem.Biotechnol. pp: 121-124, pp: 105-116.

17. HarwoodJ (1989) The versatility of lipases for industrial uses. Trends Biochem. Sci.14, 125-126.

18. lluyemi FB, Hanafi MM, Radziah $\mathrm{O}$ and Kamarudin MS (2006) Fungal solid state culture of palm kernel cake. Bioresour. Technol. 97, 477-484.

19. Immanuel G, Esakkiraj $P$, Austin JG, lyapparaj $P$ and Palavesam A (2008) Investigation of lipase production by milk isolate Serratia rubidaea. Food Technol.Biotechnol. 46, 60-65.

20.Jaeger KE and Reetz MT (1998) Microbial lipases form versatile tools in biotechnology. Trends Biotechnol. 16, 396-403.

21.Jayaprakash A and Ebenezer P (2010) Investigation on extracellular lipase production by Aspergillus japonicus isolated from the paper nest of Ropalidia marginata. Indian J.Sci. Technol. 3 (2), 113-117.

22.Kamini NR, Mala JGS and Puvanakrishnan R (1998) Lipase production from Aspergillus niger by solid-state fermentation using gingelly oil cake. Process Biochem. 33, 505-511.

23. Kishore Patil J, Manojkumar Chopda Z and Raghunath Mahajan T. (2011) Lipase biodiversity. Indian J.Sci. Technol. 4 (8), 971-982.

24.Kwon DY and Rhee JS (1986) A simple and rapid colorimetric method for determination of free fatty acids for lipase assay. J. Am. Oil Chem. Soc. 63, 8992. 
25.Lee JH, Kim SB, Kang SW, Seok SY, Chulhwan P, Sung OKH and Seung WK (2011) Biodiesel production by a mixture of Candida rugosa and Rhizopus oryzae lipases using a supercritical carbon dioxide process. Bioresour. Technol.102, 2105-2108.

26. Lowry OH, Rosebrough NJ, Farr AL and Randall RJ (1951) Protein measurement with folinphenol reagent. J. Biol. Chem.193, 265-275.

27. Manfred Reetz T (2002) Lipases as practical biocatalysts. Curr.Opin. Chem. Biol. 6, 145-150.

28.Pandey A, Soccol CR, Nigam P and Soccol VT (2000) Biotechnological potential of agro-industrial residues, I: Sugarcane bagasse. Bioresour. Technol.74, 69-80.

29.PandeyA, Benjamin S, Soccol CR, Nigam P, Krieger N and Soccol VT (1999) The realm of microbial lipases in biotechnology. Biotechnol.Appl.Biochem.29, 119131.

30.PogakuP, Suresh A, Srinivas P and Reddy SR (2010) Optimization of lipase production by Staphylococcussp. Lp12. Afr. J.Biotechnol.9, 882-886.

31.Puvanakrishnan R and Dhar SC (1988) Enzyme Technology in Beamhouse Practice. Enzymes in Dehairing, NICLAI Publication, Chennai, India. pp: 92120.

32.Sangeetha R, Arulpandi I and Geetha A (2011) Bacterial lipases as potential industrial biocatalysts: An overview. Res. J.Microbiol. 6, 1-24.

33.Saxena RK, Davidson WS, Sheoran A and Giri B (2003) Purification and characterization of an alkaline thermostable lipase from Aspergillus carneus. Process Biochem. 39, 239-247.

34. Solis-Pereira S, Favela-Torres E, Viniegra-Gonzalez G and Gutierrez-Rojas M (1993) Effects of different carbon sources on the synthesis of pectinase by Aspergillus niger in submerged and solid state fermentations. Appl. Microbiol. Technol. 39, 36-41.

35.Szendefy J, Szakacs G and Christopher L (2006) Potential of solid-state fermentation enzymes of Aspergillus oryzae in biobleaching of paper pulp. Enzyme Microbiol. Technol. 39, 1354-1360.

36. Toshiko $\mathrm{K}$, Mari $\mathrm{T}$, Ishii $\mathrm{T}$, Itoth $\mathrm{Y}$, Kirimura $\mathrm{K}$ and Usami S (1989) Production of lipase by Rhizopus oligosporous- A newly isolated fungus. J.HokokuWaseda .50, 61-65.

37.Wang D, Xu Y and Shan T (2008) Effects of oils and oil-related substrates on the synthetic activity of membrane-bound lipase from Rhizopuschinensis and optimization of the lipase fermentation media. Biochem.Eng.J. 41, 30-37.

38. Yang JK, Shih IL, Tzeng YM and Sang SL (2000) Production and purification of protease from a Bacillus subtilis that can deproteinise crustacean wastes. Enzyme Microbiol. Technol. 26, 406-413.

39.Zhang KP, LaiJQ, Huang ZL and Yang Z (2011) Penicillium expansum lipase-catalyzed production of biodiesel in ionic liquids. Bioresour.Technol.102, 2767-2772. 